\title{
Highly Pathogenic Avian Influenza Viruses and Generation of Novel Reassortants, United States, 2014-2015
}

\section{Dong-Hun Lee, Justin Bahl, Mia Kim Torchetti, Mary Lea Killian, Hon S. Ip, Thomas J. DeLiberto, David E. Swayne}

Asian highly pathogenic avian influenza $A(H 5 N 8)$ viruses spread into North America in 2014 during autumn bird migration. Complete genome sequencing and phylogenetic analysis of $32 \mathrm{H} 5$ viruses identified novel H5N1, H5N2, and H5N8 viruses that emerged in late 2014 through reassortment with North American low-pathogenicity avian influenza viruses.

$\mathrm{H}$ ighly pathogenic avian influenza (HPAI) viruses cause systemic infection and high mortality in poultry species and belong to either the $\mathrm{H} 5$ or $\mathrm{H} 7$ hemagglutinin (HA) subtypes. In particular, the Asian-origin influenza A(H5N1) A/goose/Guangdong/1/1996 (Gs/GD) lineage of HPAI viruses has become widespread across 4 continents, affecting poultry, wild birds, and humans (1).

The H5N1 HPAI virus has evolved into 10 genetically distinct virus clades (0-9) and subclades (2). During 20052006, clade 2.2 viruses spread from Qinghai Lake, China, to countries across Asia, Europe, and Africa (3). Since 2008, HPAI viruses bearing the HA gene of the Gs/GD lineage H5 clade 2.3.4 with N2, N5, and N8 neuraminidase (NA) subtypes have been identified in mainland China $(4,5)$. In early 2014, outbreaks of novel reassortant H5N6 viruses of clade 2.3.4.4 HA were reported in China, Laos, and Vietnam (6) and of H5N8 viruses of the same clade in Japan and South Korea (7). Subsequently, H5 clade 2.3.4.4 HPAI viruses originating in East Asia were detected in countries of Asia and Europe and, in late 2014, in North America (8). Since first being identified in the Pacific Northwest of the United States, HPAI viruses have been detected in 21 states. Approximately 7.5 million turkeys and 42.1 million

Author affiliations: US Department of Agriculture Agricultural Research Service, Athens, Georgia, USA (D.-H. Lee, D.E. Swayne); University of Texas School of Public Health, Houston, Texas, USA (J. Bahl); US Department of Agriculture Animal and Plant Health Inspection Service, Ames, lowa, USA (M.K. Torchetti, M.L. Killian); US Department of the Interior US Geological Survey, Madison, Wisconsin, USA (H.S. Ip); US Department of Agriculture Animal and Plant Health Inspection Service, Fort Collins, Colorado, USA (T.J. DeLiberto)

DOI: http://dx.doi.org/10.3201/eid2207.160048 chickens have died or have been depopulated as a result (https://www.aphis.usda.gov/wps/portal/aphis/ourfocus/ animalhealth/sa_animal_disease_information).

In this study, we conducted a comparative phylogenetic analysis of 32 newly sequenced H5 clade 2.3.4.4 HPAI viruses identified in the United States, including 2 H5N1, $12 \mathrm{H} 5 \mathrm{~N} 2$, and $18 \mathrm{H} 5 \mathrm{~N} 8$ viruses, to estimate the evolutionary history and to elucidate diversification patterns since emergence in North America. The methods used are detailed in online Technical Appendix 1 (http://wwwnc.cdc. gov/EID/article/22/7/16-0048-Techapp1.pdf).

Phylogenetic analyses confirmed the wide geographic dispersion of Gs/GD-lineage $\mathrm{H} 5$ clade 2.3.4.4 HPAI viruses since late 2014 and movement of this virus from East Asia to North America, West Asia, and Europe (online Technical Appendix 1 Figure 1). High bootstrap values (>70\%) and long branches in the HA phylogeny supported the delineation of these viruses into 4 groups (online Technical Appendix 1 Figure 2). Group intercontinental A (icA) comprises H5N8 viruses identified from China in early 2014 and South Korea, Japan, Taiwan, Canada, the United States, and European countries. The estimated time to most recent common ancestor (tMRCA) was June 2013 (95\% Bayesian credible interval [BCI] April-October 2013). Group icA includes reassortant $\mathrm{H} 5 \mathrm{~N} 2$ and $\mathrm{H} 5 \mathrm{~N} 3$ viruses from Taiwan and $\mathrm{H} 5 \mathrm{~N} 1$ and $\mathrm{H} 5 \mathrm{~N} 2$ viruses from North America. Group B comprises H5N8 viruses identified from China in 2013 and Korea in 2014 (tMRCA April 2013, 95\% BCI October 2012-August 2013). Group C comprises H5N6 viruses identified from China and Laos during 2013-2014 and H5N1 viruses identified from China and Vietnam in 2014 (tMRCA November 2012, 95\% BCI March 2012-May 2013). Group D comprises H5N6 viruses identified from China and Vietnam during 2013-2014, including isolates from infected humans (A/Sichuan/26221/2014[H5N6] and A/Guangzhou/39715/2014 [H5N6]) (tMRCA September 2012, 95\% BCI February 2012-February 2013). These H5 reassortant viruses were descendants of clade 2.3.4 H5N1 viruses identified in 2005 (online Technical Appendix 1 Figure 1).

Previous studies reported novel reassortant $\mathrm{H} 5 \mathrm{~N} 1$ and H5N2 viruses of group icA $(9,10)$; the H5N1 and H5N2 viruses we sequenced in this study in had identical genome constellations (Figure; Technical Appendix 1 Figures $3-5)$. Reassortment events after the initial introduction of a 
Figure. Schematic diagram of the $\mathrm{H} 5$ clade 2.3.4.4 highly pathogenic avian influenza virus genotypes identified in this study, United States, 2014-2015. Reassortant H5N8 comprises Eurasian PB2, $\mathrm{PA}, \mathrm{HA}, \mathrm{NP}, \mathrm{M}$, and NS gene segments, and North American PB1 and PA gene segments; reassortant H5N2 comprises Eurasian PB2, PA, HA, M, and NS gene segments, and North American NA, PB1, and NP gene segments; reassortant $\mathrm{H} 5 \mathrm{~N} 1$ comprises Eurasian HA, NP, M, and PB2 gene segments and North American NA, NS, PA, and PB1 gene segments. HA, hemagglutinin; LPAI, low-pathogenicity avian influenza; M, matrix; NA, neuraminidase; NP, nucleoprotein; NS, nonstructural; PA, polymerase acidic; PB1, polymerase basic 1; PB2, polymerase basic 2 .

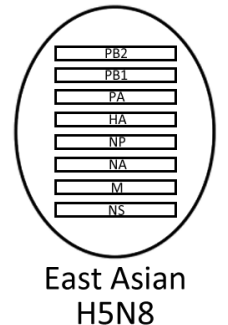

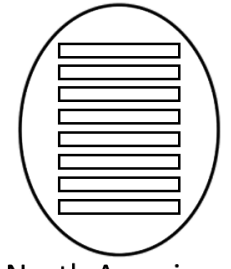

North American North American H5N8

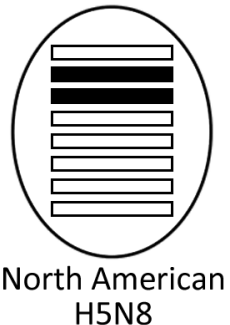

H5N8

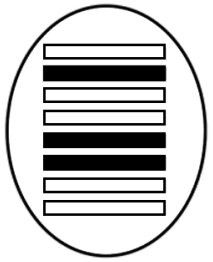

H5N2

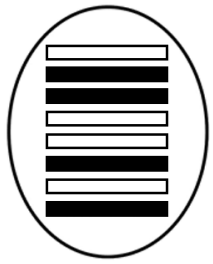

H5N 1

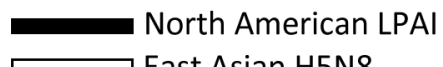

North American group icA $\mathrm{H} 5 \mathrm{~N} 8$ virus to low-pathogenicity avian influen$\mathrm{za}$ (LPAI) viruses led to the divergence of $\mathrm{H} 5$ viruses into distinct subtypes, including H5N1, H5N2, and reassortant H5N8. Sixteen H5N8 viruses sequenced in this study had identical genome constellations with previously reported H5N8 viruses from East Asia. In addition, 2 H5N8 reassortant isolates identified from Oregon in January 2015 (A/ American wigeon/Oregon/AH0012525/2015 and A/Canada goose/Oregon/AH0012452/2015) had polymerase basic 1 and polymerase acidic genes derived from North American lineage LPAI viruses that did not cluster with the H5N1 and $\mathrm{H} 5 \mathrm{~N} 2$ reassortant viruses (online Technical Appendix 1 Figure 5). Ongoing analysis of existing wild bird surveillance data might aid in filling in the relatively long horizontal branches of the NA and internal genes of $\mathrm{H} 5$ reassortant viruses derived from North American LPAI viruses. The occurrence of multiple reassortment events means that group icA H5N8 virus was infecting the same wild birds that were infected with North American LPAI viruses but also that the tissue tropism of Asian H5N8 HPAI and North
American LPAI viruses were overlapping, most likely in the cells lining the respiratory and intestinal tract (11).

The estimated tMRCA of $\mathrm{H} 5$ viruses identified in the United States was October 2014 (95\% BCI July-November 2014). The estimated tMRCA of reassortant viruses identified in the United States was December 2014 for H5N1 (95\% BCI December 2014-December 2014), November 2014 for H5N2 (95\% BCI October 2014-November 2014), and December 2014 for H5N8 (95\% BCI November 2014-January 2015) (Table). The tMRCA of $\mathrm{H} 5 \mathrm{~N} 8$ viruses corresponded to the autumn bird migration season, supporting the hypothesis that Eurasian H5N8 clade 2.3.4.4 virus spread via migratory birds $(8,12,13)$. Subsequently, H5N2 reassortant viruses emerged in November 2014, and $\mathrm{H} 5 \mathrm{~N} 1$ and $\mathrm{H} 5 \mathrm{~N} 8$ reassortant viruses emerged in December 2014 (Table; online Technical Appendix 1 Figures 3-5).

Wild bird migration and illegal trade of infected poultry, eggs, and poultry products have caused the spread of HPAI viruses (14). The South Korea H5N8 outbreak in January

\begin{tabular}{|c|c|c|c|c|}
\hline \multirow[b]{2}{*}{ Gene } & \multicolumn{4}{|c|}{ tMRCA (95\% BCI, posterior probability) } \\
\hline & H5N8 & H5N8 reassortant & H5N1 reassortant & H5N2 reassortant \\
\hline $\mathrm{HA}$ & $\begin{array}{c}\text { Oct 2014 } \\
(\text { Jul 2014-Nov 2014, } 0.81)\end{array}$ & $\begin{array}{c}\text { Dec } 2014 \\
(\text { Nov 2014-Jan 2015, 0.67) }\end{array}$ & $\begin{array}{c}\text { Dec } 2014 \\
(\text { Dec 2014-Dec 2014, 1.00) }\end{array}$ & $\begin{array}{c}\text { Nov } 2014 \\
\text { (Oct 2014-Nov 2014, } 0.99)\end{array}$ \\
\hline NA & Jul 2014 & Dec 2014 & Mar 2014 & \\
\hline PB2 & $\begin{array}{c}\text { (Feb 2014-Nov 2014, 0.76) } \\
\text { Oct 2014 } \\
\text { (Aug 2014-Nov 2014, 1.00) }\end{array}$ & $\begin{array}{c}\text { (Nov 2014-Jan 2015, 1.00) } \\
\text { Dec 2014 } \\
\text { (Oct 2014- Jan 2015, 0.48) }\end{array}$ & $\begin{array}{c}\text { (Jul 2013-Oct 2014, 1.00) } \\
\text { Nov 2014 } \\
\text { (Oct 2014-Dec 2014, 0.95) }\end{array}$ & $\begin{array}{c}\text { (Jun 2014- Nov 2014, 1.00) } \\
\text { Nov } 2014 \\
\text { (Oct 2014- Nov 2014, 0.99) }\end{array}$ \\
\hline PB1 & $\begin{array}{c}\text { Oct 2014 } \\
\text { (Jul 2014-Nov 2014, 1.00) }\end{array}$ & $\begin{array}{c}\text { Dec 2014 } \\
\text { (Nov 2014-Jan 2015, 1.00) }\end{array}$ & $\begin{array}{c}\text { Dec 2014 } \\
\text { (Nov 2014-Dec 2014, 1.00) }\end{array}$ & $\begin{array}{c}\text { Oct 2014 } \\
\text { (Aug 2014- Nov 2014, 1.00) }\end{array}$ \\
\hline PA & $\begin{array}{c}\text { Sep } 2014 \\
\text { (Jul 2014-Nov 2014, 0.38) }\end{array}$ & $\begin{array}{c}\text { Nov 2014 } \\
\text { (Sep 2014-Jan 2015, 1.00) }\end{array}$ & $\begin{array}{c}\text { Nov 2014 } \\
\text { (Oct 2014-Dec 2014, 0.98) }\end{array}$ & $\begin{array}{c}\text { Oct } 2014 \\
\text { (Sep 2014-Nov 2014, 1.00) }\end{array}$ \\
\hline NP & $\begin{array}{c}\text { Jul } 2014 \\
\text { (Mar 2014-Nov 2014, 0.53) }\end{array}$ & $\begin{array}{c}\text { Nov } 2014 \\
\text { (Jul 2014-Jan 2015, 0.67) }\end{array}$ & $\begin{array}{c}\text { Nov 2014 } \\
\text { (Oct 2014-Dec 2014, 1.00) }\end{array}$ & $\begin{array}{c}\text { Nov 2014 } \\
\text { (Jun 2014-Nov 2014, 1.00) }\end{array}$ \\
\hline M & $\begin{array}{c}\text { Jul } 2014 \\
\text { (Jan 2014-Dec 2014, 0.95) }\end{array}$ & $\begin{array}{c}\text { Nov } 2014 \\
\text { (Jun 2014-Jan 2015, 0.38) }\end{array}$ & $\begin{array}{c}\text { Dec } 2014 \\
\text { (Nov 2014-Dec 2014, 1.00) }\end{array}$ & $\begin{array}{c}\text { Aug } 2014 \\
\text { (Mar 2014-Nov 2014, 0.34) }\end{array}$ \\
\hline NS & $\begin{array}{c}\text { May 2014 } \\
\text { (Nov 2013-Nov 2014, 0.08) }\end{array}$ & $\begin{array}{c}\text { Dec 2014 } \\
\text { (Nov 2014-Jan 2015, 1.00) }\end{array}$ & $\begin{array}{c}\text { Nov } 2014 \\
\text { (Sep 2014-Dec 2014, 1.00) }\end{array}$ & $\begin{array}{c}\text { May 2014 } \\
\text { (Oct 2013-Oct 2014, 0.86) }\end{array}$ \\
\hline
\end{tabular}

${ }^{*} \mathrm{BCl}$, Bayesian credible interval; HA, hemagglutinin; M, membrane; NA, neuraminidase; NP, nucleoprotein; NS, nonstructural; PA, polymerase acidic; $\mathrm{PB} 1$, polymerase basic 1; PB2, polymerase basic 2; tMRCA, time to most recent common ancestor. 
2014 was the first H5N8 virus reported outside of China. Wild migratory birds were suspected to play a key role in the introduction of group ic A and B viruses from eastern China and in the subsequent spread during the 2014 South Korea outbreak (15). Previous studies hypothesized that wild bird migration might play a role in dispersal of these viruses; the H5N8 virus was identified in a long-distance migrant bird (Eurasian wigeon, Anas penelope) in eastern Siberia in September 2014 and subsequently in multiple wild bird species in Japan, Europe, and the west coast of North America in November and December 2014 (8,12). In contrast, group C H5N6 HPAI viruses in Laos were most likely transmitted by live poultry imports from China (6).

The continued reassortment of $\mathrm{H} 5$ clade 2.3.4.4 HPAI viruses with co-circulating HPAI and LPAI viruses created a diverse genetic pool of H5 clade 2.3.4.4 that has spread to various countries. This contrasts with the expansion of H5N1 clade 2.2 from Asia to Western Europe during 2005-2006, when such frequent reassortment was not recorded. In eastern China, H5N2 HPAI viruses isolated in 2011 were generated from reassortment events in which the neuraminidase and nonstructural gene segments of $\mathrm{H} 5 \mathrm{~N} 1$ HPAI viruses were replaced with those derived from locally circulating LPAI viruses (4). The H5N8 viruses of group B had polymerase basic 2 , neuraminidase, and nonstructural genes derived from local LPAI viruses (5). The $\mathrm{H} 5 \mathrm{~N} 6$ viruses of group C identified in Laos were generated through reassortment between $\mathrm{H} 5 \mathrm{~N} 1$ viruses from clade 2.3.2.1b, clade 2.3.4, and H6N6 LPAI viruses that circulate broadly in duck populations in China (6).

H5 clade 2.3.4.4 viruses have spread globally through wild bird migration and the poultry trade $(6,8,12,13)$. In addition, these viruses generated a variety of reassortant viruses that shuffled genes with prevailing local viruses. The continued circulation of HPAI viruses in wild and domestic avian populations contributes to the persistence and diversity of circulating avian influenza viruses. Enhanced active surveillance provides the opportunity to monitor the spread and reassortment of clade 2.3.4.4 and to fortify the biosecurity of farms in affected regions.

\section{Acknowledgments}

We thank our colleagues worldwide for their laboratory contributions, which are made available through the Global Initiative on Sharing All Influenza Data (online Technical Appendix 2, http://wwwnc.cdc.gov/EID/article/22/7/ 16-0048-Techapp2.xlsx).

Dr. Lee is a post-doctoral researcher at the Southeast Poultry Research Laboratory, Animal Research Service, US Department of Agriculture. His research interests include the molecular epidemiology, evolution, and vaccinology of avian influenza viruses.

\section{References}

1 Swayne DE, Suarez DL, Sims LD. Influenza. In: Swayne DE, Glisson JR, McDougald LR, Nair V, Nolan LK, Suarez DL, editors. Diseases of poultry, 13th edition. Ames (Iowa): Wiley-Blackwell; 2013. p. 181-218.

2. WHO/OIE/FAO H5N1 Evolution Working Group. Toward a unified nomenclature system for highly pathogenic avian influenza virus (H5N1). Emerg Infect Dis. 2008;14:e1. http://dx.doi.org/10.3201/ eid1407.071681

3. Salzberg SL, Kingsford C, Cattoli G, Spiro DJ, Janies DA, Aly MM, et al. Genome analysis linking recent European and African influenza (H5N1) viruses. Emerg Infect Dis. 2007;13:7138. http://dx.doi.org/10.3201/eid1305.070013

4. Zhao G, Gu X, Lu X, Pan J, Duan Z, Zhao K, et al. Novel reassortant highly pathogenic $\mathrm{H} 5 \mathrm{~N} 2$ avian influenza viruses in poultry in China. PLoS One. 2012;7:e46183. http://dx.doi.org/ 10.1371/journal.pone.0046183

5. Wu H, Peng X, Xu L, Jin C, Cheng L, Lu X, et al. Novel reassortant influenza $\mathrm{A}(\mathrm{H} 5 \mathrm{~N} 8)$ viruses in domestic ducks, eastern China. Emerg Infect Dis. 2014;20:1315-8. http://dx.doi.org/ 10.3201/eid2008.140339

6. Wong FY, Phommachanh P, Kalpravidh W, Chanthavisouk C, Gilbert J, Bingham J, et al. Reassortant highly pathogenic influenza A(H5N6) virus in Laos. Emerg Infect Dis. 2015;21:511-6. http://dx.doi.org/10.3201/eid2103.141488

7. Lee YJ, Kang HM, Lee EK, Song BM, Jeong J, Kwon YK, et al. Novel reassortant influenza A(H5N8) viruses, South Korea, 2014. Emerg Infect Dis. 2014;20:1087-9. http://dx.doi.org/10.3201/ eid2006.140233

8. Lee DH, Torchetti MK, Winker K, Ip HS, Song CS, Swayne DE. Intercontinental spread of Asian-origin H5N8 to North America through Beringia by migratory birds. J Virol. 2015;89:6521-4. http://dx.doi.org/10.1128/JVI.00728-15

9. Torchetti MK, Killian ML, Dusek RJ, Pedersen JC, Hines N, Bodenstein B, et al. Novel H5 clade 2.3.4.4 reassortant (H5N1) virus from a green-winged teal in Washington, USA. Genome Announc. 2015;3:e0195-15. http://dx.doi.org/10.1128/ genomeA.00195-15

10. Ip HS, Torchetti MK, Crespo R, Kohrs P, DeBruyn P, Mansfield $\mathrm{KG}$, et al. Novel Eurasian highly pathogenic avian influenza A H5 viruses in wild birds, Washington, USA, 2014. Emerg Infect Dis. 2015;21:886-90. http://dx.doi.org/10.3201/eid2105.142020

11. Webster RG, Yakhno M, Hinshaw VS, Bean WJ, Murti KG. Intestinal influenza: replication and characterization of influenza viruses in ducks. Virology. 1978;84:268-78. http://dx.doi.org/10.1016/ 0042-6822(78)90247-7

12. Verhagen JH, Herfst S, Fouchier RA. Infectious disease. How a virus travels the world. Science. 2015;347:616-7. http://dx.doi.org/10.1126/science.aaa6724

13. Saito T, Tanikawa T, Uchida Y, Takemae N, Kanehira K, Tsunekuni R. Intracontinental and intercontinental dissemination of Asian H5 highly pathogenic avian influenza virus (clade 2.3.4.4) in the winter of 2014-2015. Rev Med Virol. 2015;25:388-405. http://dx.doi.org/10.1002/rmv.1857

14. Suarez DL. Avian influenza: our current understanding. Anim Health Res Rev. 2010;11:19-33. http://dx.doi.org/10.1017/ S1466252310000095

15. Jeong J, Kang HM, Lee EK, Song BM, Kwon YK, Kim HR, et al. Highly pathogenic avian influenza virus (H5N8) in domestic poultry and its relationship with migratory birds in South Korea during 2014. Vet Microbiol. 2014;173:249-57. http://dx.doi.org/ 10.1016/j.vetmic.2014.08.002

Address for correspondence: David E. Swayne, Agricultural Research Service, U.S. Department of Agriculture, 934 College Station Rd, Athens, GA 30605, USA; email: david.swayne@ars.usda.gov 